\title{
Morphometric Study of the Eyeball of Three Breeds of Goats in Nigeria
}

\author{
Estudio Morfométrico del Bulbo Ocular de Tres Razas de Cabras en Nigeria \\ "Olopade, James Olukayode; "** Kwari, Hyelduku Danladi; *Agbashe, Isabella Onome \& *Onwuka, Silas Kalu
}

OLOPADE, J. O.; KWARI, H. D.; AGBASHE, I. O. \& ONWUKA, S. K. Morphometric study of the eyeball of three breeds of goat in Nigeria. Int. J. Morphol., 23(4):377-380, 2005.

SUMMARY: A comparative study of ocular morphometry was done in goats in Nigeria using the three major breeds. The result showed that the circumferences (mediolateral and anteriorposterior) were fairly constant between the breeds. The mean relative eyeball weight ranged from $(0.39-0.59) \times 10-3$. Asymmetry was observed between the right and left eyeball weights and circumferences in all breeds and there was disparity in the asymmetry. It was also observed that heavier eyeball weights did not always correspond to a wider circumference. Female WAD and RS goats had significantly heavier $(\mathrm{p}<0.05)$ eyeball weights than the males but that was not the case in the Sahel breed. Animals above one year had consistently higher values in most of the parameters examined on the eye than those below the age group. The results are added information to baseline data on regional anatomy of the head of small ruminant breeds in Nigeria and for comparative ocular studies.

KEY WORDS: Eyeball; Goats; Morphometry; Nigeria.

\section{INTRODUCTION}

The eye is one of the most complex organs in the body which gives us a sense of sight allowing humans and animals to learn more about the surrounding world. The eye is like a camera; light let on by the cornea is controlled by the pupil and is charged into electrical signals by the retina and sent to the brain where the signals are interpreted into visual images (Guyton, 1989). The eye is composed of globe or eyeball, the optic nerves and the accessory structures; eyeballs, conjunctivae, lacrimal apparatus and extraocular muscles (Dyce, 2002).

Goats are hardy animals and ubiquitous in Nigeria (Osuagwuh, 2002). While increasing amount of studies is being done in goat breeds in Nigeria, the regional anatomy of the head suffers relatively from lack of research attention; thus apart from our report of ocular morphometry of West African dwarf (WAD) in south west Nigeria (Olopade and Onwuka, 2004), there is a dearth of baseline data on ocular morphometry of goat breeds in literature.

The essence of this study is to provide a comparative morphometric data on the eyeball of the three major breeds of goats in Nigeria.

\section{MATERIALS AND METHOD}

A total of 76 eyeballs from three breeds of goats were used for this study. The Sahel, Red Sokoto (RS) and WAD goats were from the northeast, northwest and southeastern parts of Nigeria, respectively. The heads of the goats were severed and immediately frozen at $-20^{\circ} \mathrm{C}$.

Removal of Eyeballs: The eyeballs were removed according to the methods of Keller (1975). Briefly, the eyelids were sutured together with continuous suture pattern from the media to lateral canthus; the lids were then held and pulled out with an artery forceps and a scalpel knife was used to cut around the periorbital as traction was applied to the lids. This exposed the globe and after further incision was made around the orbit, the optic nerve was reached and severed. The eye was then put on the dissecting board and the eyelids, periorbital fat and connective tissue were removed to free the eye globe before it was put into $0.9 \%$ saline.

Weighing of Eyeballs: The balls were weighted in nylon surgical gloves whose weight was first determined and both weighted in a microwa swiss machine ${ }^{\circ}$. The weight difference was then taken.

Department of Veterinary Anatomy, University of Ibadan, Ibadan, Nigeria. Department of Veterinary Anatomy, University of Maiduguri, Maiduguri, Nigeria. 
Ocular Dimensions. Using a thin twine with a needle at one end for guidance, measurements were made on the mediolateral and anteriorposterior borders (circumferences).
All values obtained were subjected to statistical analysis using student's " $t$ " test . Significantly higher than WAD age one and below at $\mathrm{p}<0.1$.

\section{RESULTS}

Table I. Mean ocular morphometric dimensions of three different breeds of goats in Nigeria.

\begin{tabular}{|c|c|c|c|c|c|c|c|c|c|c|}
\hline & WOA (kg) & $\begin{array}{c}\text { WOH } \\
(\mathrm{kg})\end{array}$ & $\begin{array}{l}\text { WOE } \\
\mathrm{L}(\mathrm{g})\end{array}$ & $\begin{array}{l}\text { WOE } \\
\text { R(g) }\end{array}$ & $\begin{array}{l}\text { WOE/ } \\
\text { WOA(L) } \\
\times 10^{-3}\end{array}$ & $\begin{array}{l}\text { WOE/ } \\
\text { WOA(R) } \\
\times 10^{-3}\end{array}$ & $\begin{array}{c}\mathrm{CO} 1 \\
\mathrm{~L}(\mathrm{~cm})\end{array}$ & $\begin{array}{c}\mathrm{CO} 1 \\
\mathrm{R}(\mathrm{cm})\end{array}$ & $\begin{array}{c}\mathrm{CO} 2 \\
\mathrm{~L}(\mathrm{~cm})\end{array}$ & $\begin{array}{c}\mathrm{CO} 2 \\
\mathrm{R}(\mathrm{cm})\end{array}$ \\
\hline Sahel & $\begin{array}{l}19.11 \\
\pm 3.61\end{array}$ & $\begin{array}{l}1.26 \\
\pm 0.25\end{array}$ & $\begin{array}{l}7.43 \\
\pm 1.12\end{array}$ & $\begin{array}{l}7.27 \\
\pm 0.95\end{array}$ & $\begin{array}{l}0.40 \\
\pm 0.06\end{array}$ & $\begin{array}{l}0.39 \\
\pm 0.07\end{array}$ & $\begin{array}{l}8.17 \\
\pm 0.38\end{array}$ & $\begin{array}{l}8.23 \\
\pm 0.45\end{array}$ & $\begin{array}{l}7.11 \\
\pm 0.44\end{array}$ & $\begin{array}{l}7.19 \\
\pm 0.46\end{array}$ \\
\hline WAD & $\begin{array}{r}12.83 \\
\pm 3.10\end{array}$ & $\begin{array}{l}0.80 \\
\pm 0.20\end{array}$ & $\begin{array}{l}7.17 \\
\pm 1.66\end{array}$ & $\begin{array}{l}7.19 \\
\pm 1.39\end{array}$ & $\begin{array}{l}0.56 \\
\pm 0.22\end{array}$ & $\begin{array}{l}0.59 \\
\pm 0.22\end{array}$ & $\begin{array}{l}8.19 \\
\pm 0.61\end{array}$ & $\begin{array}{l}8.35 \\
\pm 0.53\end{array}$ & $\begin{array}{l}7.20 \\
\pm 0.58\end{array}$ & $\begin{array}{l}7.18 \\
0.58\end{array}$ \\
\hline RS & $\begin{array}{r}18.66 \\
\pm 5.99\end{array}$ & $\begin{array}{l}1.20 \\
\pm 0.39\end{array}$ & $\begin{array}{l}8.68 \\
\pm 0.78\end{array}$ & $\begin{array}{l}7.92 \\
\pm 0.59\end{array}$ & $\begin{array}{l}0.46 \\
\pm 0.07\end{array}$ & $\begin{array}{l}0.45 \\
\pm 0.06\end{array}$ & $\begin{array}{l}8.42 \\
\pm 0.26\end{array}$ & $\begin{array}{l}8.58 \\
\pm 0.26\end{array}$ & $\begin{array}{l}7.41 \\
\pm 0.15\end{array}$ & $\begin{array}{l}7.46 \\
\pm 0.26\end{array}$ \\
\hline
\end{tabular}

Table II. Mean ocular morphometric dimensions of three different breeds of goats in Nigeria. Effect of sex.

\begin{tabular}{|c|c|c|c|c|c|c|c|c|c|c|}
\hline & $\begin{array}{c}\text { WOA } \\
(\mathrm{kg})\end{array}$ & $\begin{array}{c}\text { WOH } \\
(\mathrm{kg})\end{array}$ & $\begin{array}{l}\text { WOE } \\
\mathrm{L}(\mathrm{g})\end{array}$ & $\begin{array}{l}\text { WOE } \\
R(g)\end{array}$ & $\begin{array}{l}\text { WOE/ } \\
\text { WOA(L) } \\
\times 10^{-3}\end{array}$ & $\begin{array}{l}\mathrm{WOE} / \\
\mathrm{WOA}(\mathrm{R}) \\
\times 10^{-3}\end{array}$ & $\begin{array}{l}\mathrm{CO} 1 \\
\mathrm{~L}(\mathrm{~cm})\end{array}$ & $\begin{array}{l}\text { CO1 } \\
\mathrm{R}(\mathrm{cm})\end{array}$ & $\begin{array}{l}\mathrm{CO} 2 \\
\mathrm{~L}(\mathrm{~cm})\end{array}$ & $\begin{array}{l}\mathrm{CO} 2 \\
\mathrm{R}(\mathrm{cm})\end{array}$ \\
\hline Sahel & 18.78 & 1.31 & 7.43 & 7.27 & 0.40 & 0.39 & 8.14 & 8.12 & 7.09 & 7.17 \\
\hline Male & \pm 2.39 & \pm 0.23 & \pm 0.87 & \pm 0.73 & \pm 0.05 & \pm 0.05 & \pm 0.34 & \pm 0.53 & \pm 0.37 & \pm 0.46 \\
\hline Fem-ale & $\begin{array}{l}19.44 \\
\pm 4.67\end{array}$ & $\begin{array}{l}1.21 \\
\pm 0.26\end{array}$ & $\begin{array}{l}7.42 \\
\pm 1.37\end{array}$ & $\begin{array}{l}7.28 \\
\pm 1.18\end{array}$ & $\begin{array}{l}0.39 \\
\pm 0.07\end{array}$ & $\begin{array}{l}0.39 \\
\pm 0.08\end{array}$ & $\begin{array}{l}8.20 \\
\pm 0.44\end{array}$ & $\begin{array}{l}8.34 \\
\pm 0.36\end{array}$ & $\begin{array}{l}7.13 \\
\pm 0.52\end{array}$ & $\begin{array}{l}7.21 \\
\pm 0.49\end{array}$ \\
\hline WAD & 14.20 & 0.96 & 5.93 & 5.88 & 0.39 & 0.38 & 7.70 & 8.16 & 6.88 & 6.82 \\
\hline Male & \pm 3.27 & \pm 0.31 & \pm 1.57 & \pm 1.22 & \pm 0.10 & \pm 0.05 & \pm 0.67 & \pm 0.74 & \pm 0.87 & \pm 0.70 \\
\hline Female & $\begin{array}{l}11.86 \\
\pm 2.76\end{array}$ & $\begin{array}{l}0.82 \\
\pm 0.10\end{array}$ & $\begin{array}{l}8.00^{*} \\
\pm 1.19\end{array}$ & $\begin{array}{l}7.94 * \\
\pm 0.82\end{array}$ & $\begin{array}{l}0.68^{*} \\
\pm 0.20\end{array}$ & $\begin{array}{l}0.70^{*} \\
\pm 0.18\end{array}$ & $\begin{array}{l}8.47 \\
\pm 0.39\end{array}$ & $\begin{array}{l}8.50 \\
\pm 0.0\end{array}$ & $\begin{array}{l}7.39 \\
\pm 0.27\end{array}$ & $\begin{array}{l}7.43 \\
\pm 0.35\end{array}$ \\
\hline $\begin{array}{l}\text { RS } \\
\text { Male }\end{array}$ & $\begin{array}{l}13.25 \\
\pm 0.75\end{array}$ & $\begin{array}{l}0.93 \\
\pm 0.15\end{array}$ & $\begin{array}{l}6.35 \\
\pm 0.65\end{array}$ & $\begin{array}{l}6.43 \\
\pm 0.48\end{array}$ & $\begin{array}{l}0.50 \\
\pm 0.09\end{array}$ & $\begin{array}{l}0.49 \\
\pm 0.05\end{array}$ & $\begin{array}{l}7.87 \\
\pm 0.29\end{array}$ & $\begin{array}{l}8.07 \\
\pm 0.15\end{array}$ & $\begin{array}{l}7.17 \\
\pm 0.03\end{array}$ & $\begin{array}{l}6.97 \\
\pm 0.19\end{array}$ \\
\hline Female & $\begin{array}{r}22.99 \\
\pm 5.60\end{array}$ & $\begin{array}{l}1.33 \\
\pm 0.10\end{array}$ & $\begin{array}{l}8.96^{*} \\
\pm 0.85\end{array}$ & $\begin{array}{l}8.74 * \\
\pm 0.65\end{array}$ & $\begin{array}{l}0.44 \\
\pm 0.08\end{array}$ & $\begin{array}{l}0.42 \\
\pm 0.08\end{array}$ & $\begin{array}{l}8.70 \\
\pm 0.31\end{array}$ & $\begin{array}{l}8.83 \\
\pm 0.34\end{array}$ & $\begin{array}{l}7.53 \\
\pm 0.21\end{array}$ & $\begin{array}{l}7.70 \\
\pm 0.34\end{array}$ \\
\hline
\end{tabular}

*Significantly higher than the males at $\mathrm{p}<0.05$

Table III A: Mean ocular morphometric dimensions of three different breeds of goats in Nigeria. Effect of age. Animals one year and bellow.

\begin{tabular}{|c|c|c|c|c|c|c|c|c|c|c|}
\hline & $\begin{array}{c}\text { WOA } \\
(\mathrm{kg})\end{array}$ & $\begin{array}{c}\text { WOH } \\
(\mathrm{kg})\end{array}$ & $\begin{array}{l}\text { WOE } \\
\mathrm{L}(\mathrm{g})\end{array}$ & $\begin{array}{l}\text { WOE } \\
\text { R(g) }\end{array}$ & $\begin{array}{l}\text { WOE } \\
\text { WOA(L) } \\
\times 10^{-3}\end{array}$ & $\begin{array}{l}\text { WOE } \\
\text { WOA(R) } \\
\times 10^{-3}\end{array}$ & $\begin{array}{c}\mathrm{CO} 1 \\
\mathrm{~L}(\mathrm{~cm})\end{array}$ & $\begin{array}{c}\mathrm{CO} 1 \\
\mathrm{R}(\mathrm{cm})\end{array}$ & $\begin{array}{c}\mathrm{CO} 2 \\
\mathrm{~L}(\mathrm{~cm})\end{array}$ & $\begin{array}{c}\mathrm{CO} 2 \\
\mathrm{R}(\mathrm{cm})\end{array}$ \\
\hline \multirow[t]{2}{*}{ Sahel } & 17.92 & 1.20 & $6.93^{*}$ & 7.02 & 0.40 & 0.40 & 8.02 & 8.09 & 6.97 & 7.01 \\
\hline & \pm 3.65 & \pm 0.25 & \pm 0.94 & \pm 0.98 & \pm 0.07 & \pm 0.07 & \pm 0.36 & \pm 0.48 & \pm 0.43 & \pm 0.40 \\
\hline \multirow[t]{2}{*}{ WAD } & 13.50 & 0.63 & 5.27 & 5.27 & 0.36 & 0.35 & 7.37 & 7.98 & 6.53 & 6.55 \\
\hline & \pm 3.35 & \pm 0.46 & \pm 0.15 & \pm 0.15 & \pm 0.01 & \pm 0.03 & \pm 0.77 & \pm 0.71 & \pm 0.67 & \pm 0.40 \\
\hline RS & $\begin{array}{r}16.50 \\
\pm 4.25\end{array}$ & $\begin{array}{l}1.11 \\
\pm 0.11 \\
\end{array}$ & $\begin{array}{l}8.84 \\
\pm 1.41\end{array}$ & $\begin{array}{l}7.91 \\
\pm 1.08 \\
\end{array}$ & $\begin{array}{l}0.52 \\
\pm 0.04\end{array}$ & $\begin{array}{l}0.49 \\
0.06\end{array}$ & $\begin{array}{l}8.50 \\
\pm 0.33\end{array}$ & $\begin{array}{l}8.58 \\
\pm 0.26\end{array}$ & $\begin{array}{l}7.48 \\
\pm 0.21 \\
\end{array}$ & $\begin{array}{l}7.48 \\
\pm 0.38 \\
\end{array}$ \\
\hline
\end{tabular}

*Significantly higher than WAD at $\mathrm{p}<0.1 \quad$ A. Animals One year and Below. B. Animals Above One Year

Table IIIB: Mean ocular morphometric dimensions of three different breeds of goats in Nigeria. Effect of age. Animals above one year.

$\begin{array}{cccccccccc}\begin{array}{c}\text { WOA } \\ (\mathrm{kg})\end{array} & \begin{array}{c}\text { WOH } \\ (\mathrm{kg})\end{array} & \begin{array}{c}\text { WOE } \\ \mathrm{Lg}(\mathrm{g})\end{array} & \begin{array}{c}\text { WOE }(\mathrm{g}) \\ \mathrm{ROA} /\end{array} & \begin{array}{c}\text { WOA } / \mathrm{L}) \\ \mathrm{W} 10^{-3}\end{array} & \begin{array}{c}\text { WOE/ } \\ \mathrm{WOA}(\mathrm{R}) \\ \times 10^{-3}\end{array} & \begin{array}{c}\mathrm{CO} 1 \\ \mathrm{~L}(\mathrm{~cm})\end{array} & \begin{array}{c}\mathrm{CO} 1 \\ \mathrm{R}(\mathrm{cm})\end{array} & \begin{array}{c}\mathrm{CO} 2 \\ \mathrm{~L}(\mathrm{~cm})\end{array} & \begin{array}{c}\mathrm{CO} 2 \\ \mathrm{R}(\mathrm{cm})\end{array} \\ 21.50 & 1.38 & 8.42 & 7.78 & 0.40 & 0.37 & 8.48 & 8.52 & 7.40 & 7.55 \\ \pm 2.17 & \pm 0.20 & \pm 0.92 & \pm 0.71 & \pm 0.04 & \pm 0.06 & \pm 0.19 & \pm 0.23 & \pm 0.30 & \pm 0.36 \\ 12.50 & 0.88 & 7.99^{*} & 7.71^{*} & 0.65^{*} & 0.67^{*} & 8.50 & 8.61 & 7.45 & 7.49 \\ \pm 3.16 & \pm 0.19 & \pm 1.09 & \pm 0.77 & \pm 0.18 & \pm 0.16 & \pm 0.37 & \pm 0.28 & \pm 0.31 & \pm 0.36 \\ 20.40 & 1.27 & 8.56 & 7.94 & 0.41 & 0.42 & 8.36 & 8.58 & 7.36 & 7.44 \\ \pm 5.84 & \pm 0.17 & \pm 1.04 & \pm 0.74 & \pm 0.07 & \pm 0.07 & \pm 0.41 & \pm 0.44 & \pm 0.22 & \pm 0.39\end{array}$

$\mathrm{WOA}=$ Weight of animal; $\mathrm{WOH}=$ Weight of head; $\mathrm{WOE}=$ Weight of eyeball; CO1 = Mediolateral circumference of eyeball; CO2: Anteriorposteroir circumference of yeball; $\mathrm{L}=$ Left; $\mathrm{R}=$ Right. 
The mean eyeball weight of this study were $7.43 \mathrm{~g}, 7.27$; 7.17, 7.19g and 8.68, 7.92g for left and right of Sahel, WAD and RS goats, respectively.

There was also a strong positive correlation between the left and rights relative eyeball weights in females of WAD and Sahel goats.

The mean mediolateral and anteriorposterior circumferences ( $\mathrm{C} 01$ and $\mathrm{C} 02)$ of the left and right eyeballs were $8.19,8.36,7.20,7.18 ; 8.17,8.23,7.11,7.19$ and 8.42, 8.58, 7.41, 7.46 for WAD, Sahel and RS goats, respectively. It was observed that females had wider circumferences of eyeball than males in all breeds.

Animals above one year had significantly heavier eyeball weights, wider circumference than animals below this age group in WAD and Sahel breeds. While male RS goats had heaviest eyeball weights than other males, that of the WAD females was the heaviest amongst the other females.

\section{DISCUSSION}

The mean eyeball weights of the three breeds of goats in this study were in the range of $7.17 \mathrm{~g}-8.68 \mathrm{~g}$. This is heavier than the $6.77 \mathrm{~g}$ and $3.00 \mathrm{~g}$ obtained in man and rabbits, respectively but lighter than the $23.30 \mathrm{~g}, 19 \mathrm{~g}$ and $65 \mathrm{~g}$ obtained in sheep, pig and cattle (Jaffe, 1969, Gellat, 1991) and the $100.89 \mathrm{~g}, 14.2 \mathrm{~g}$ and $10.79 \mathrm{~g}$ obtained for horse and large and small dogs, respectively (Bayer, 1914).

The mean relative eyeball weight at $\mathrm{x} 10-3$ obtained in this study for all breeds ranging from $0.39-0.59$ is higher than the $0.20,0.14,0.27,0.25$ and 0.36 obtained for horse, cow, sheep and for exotic and local pigs, respectively, but lower than the 1.83 and 3.74 obtained in small dogs and cats, respectively.

While the RS and Sahel goats had the heavier eyeball weights averagely, the WAD which is a smaller breed had higher relative eyeball weight than other breeds. The reason for this is that a lot of body weight of the larger breeds is contributed by the long limbs. There were no significant differences in the mediolateral and anteriorposterior circumferences between the breeds. These results suggest that eyeball weights and diameters are fairly constant amongst breeds in the goat. There was a positional asymmetry in the eyeball between breeds. While the left eyeball was heavier in the Sahel and RS breeds, the right was slightly heavier in the WAD. Similarly, disparity was noticed in the mediolateral and anteriorposterior circumferences between the left and right eyeballs in all breeds. This is consistent with the asymmetries that have been noticed in vertebrates (Mercola \& Levin, 2001). It is worthy of note that heavier eyeballs were not necessarily reflected in larger volumes (as the circumference is smaller in some). This indicates that the heavier weights could have resulted from differences in thickness of structures, or viscosity and weight of the eye fluids.

Female WAD and RS goats had significantly heavier ( $\mathrm{p}$ $<0.05$ ) eyeball weights and also higher values for most parameters studied than the male, but this was not so in the Sahel great indicating breed based variability in ocular morphometry between the sexes as has been seen in some other parameters in the goat (Haenlein, 2005).

Animals that are above one year have consistently higher values than animals one year and below. This may indicate a geometric increase in the shape and weight of the eyeball as the animal grows above this age.

However, for animals one year and below, significant differences $(\mathrm{p}<0.1)$ in eyeball weights occurred amongst two of the breeds (WAD and Sahel) with the latter being heavier. This weight disparity was however diminished amongst the two breeds at over the age of one indicating that while accelerated growth of the eyeball of the Sahel is more pronounced at the younger age and tapers as the animal becomes older, the WAD still experiences appreciable growth "sprouts" of the same over this age mark. One the other hand the eyeball weight of the RS remained fairly constant between these age groups accounting for the sharp decline in the relative eyeball weight as the animals grew older. This likely is due to the fact that full growth of the eyeball is achieved at a very early age in this breed; this could be hereditary, or could be due to adaptation of the breed to environmental factors since the animals were obtained from their natural environments.

The WAD goat in this study was from the southeastern part of Nigeria. We had earlier reported eyeball weights of the same breed from the southwest (Olopade \& Onwuka). This eyeball weight in this study was however slightly heavier than those obtained in the earlier study. This may be as a result of environmental factors as such disparity has been noticed in body structures of animals of the same breed living in different locations (Endo, et al., 2002).

The results has provided further information of the baseline data of ocular dimensions in small ruminant breeds in Nigeria and will be valuable in comparative ocular anatomy and regional anatomy of the head (Dyce et al.) and in the assessment of ocular pathologies (Wilk-Wilczynska et al., 1966) in this species.

ACKNOWLEDGEMENT: The authors acknowledge the technical assistance of Mr. Mark Ofua, Drs. Olanrewaju and Clinton. 
OLOPADE, J. O.; KWARI, H. D.; AGBASHE, I. O. \& ONWUKA, S. K. Estudio morfométrico del bulbo ocular de tres razas de cabras en Nigeria. Int. J. Morphol., 23(4):377-380, 2005.

RESUMEN: Se efectuó un estudio comparativo de la morfometría del bulbo ocular, en las tres razas más grandes de cabras de Nigeria. Los resultados mostraron que las circunferencias (mediolateral y anteroposterior) fueron equitativamente constantes, entre las cabras. El peso medio relativo del bulbo ocular estaba entre $(0.39-0.59 \mathrm{~g})$ x $10^{-3}$. Fueron observadas asimetrías de los pesos y circunferencias entre los bulbos oculares derecho e izquierdo, en todas las cabras y hubo disparidad en la asimetría. También fue observado que los bulbos oculares más pesados no necesariamente corresponden a los que presentan circunferencia más grande. Los pesos de los bulbos oculares de las cabras hembras WAD y RS, son signficativamente más pesadas $(\mathrm{p}<0.05)$ que los bulbos oculares de los machos, pero no es el caso en las cabras Sahel. Animales de alrededor de un año de edad tienen consistentemente valores más altos, en la mayoría de los parámetros examinados a nivel de los ojos que en los ejemplares de mayor edad. Los resultados obtenidos aumentan la información de datos de la anatomía regional de la cabeza de cabras rumiantes en Nigeria y permite estudios oculares comparativos.

\section{PALABRAS CLAVE: Bulbo ocular; Cabras; Morfometría; Nigeria.}

\section{REFERENCES}

Bayer, J. Angenheikunde. Vienna, Braumuellar, 1914.

Dyce, K. M.; Sack, W. O. \& Wensing, C. J. G. Textbook of Veterinary Anatomy. 3. ed. Philadelphia, Saunders, 2002.

Endo, H.; Hayashi, Y.; Yamazaki, K.; Motokawa, M.; Pie: JC.; Lin, L-K.; Chon, C. H. \& Oshida, T. Geographical variation of mandible size and shape in the wild pig (Sus scrofa) from Taiwan and Japan. Zoological Studies, 41(4): 452-460, 2002.

Gelatt, K. N. ed. Veterinary Ophthalmology. 2. ed. Lea \& Febiger, Philadelphia, 1991.

Guyton, D. L. Sights and Sounds in Ophthalmology. Ocular motility and Binocular vision. Mosby Co. Louis. 1989.

Haenlein, G. F. W. Recent Advances in Mineral Nutrition of Goats. Extension paper of University of Delaware. http:/ /aq.udel.edu.2005

Jaffe, N. S. The Vitreous in Clinical ophthalmology. C.V Mosby Co. St. Louis, 1969.

Keller, W. F. Enucleation of the Eyeball. In M. Joseph Bojrab's Current Technique in Small Animal Surgery, 1975.

Mercola, M \& Levin, M. Left-Right Asymmetry determination in vertebrates, Annual Review of cell and developmental Biology, 17: 779-805, 2001.

Olopade, J. O. \& Onwuka, S. K. Morphometric Studies of the Craniofacial region of the West Africa Dwarf goat in Nigeria. Int. J. Morphol., 22(2):145-8, 2004.
Osuagwuh, A. I. A. Nutritional Engineering in Mammalian Reproduction: Obstetric and Gynecologic concerns. Inaugural Lecture, University of Ibadan. Sibon books, Ibadan, 2002.

Wilk-Wilczynska, M.; Domzalowa, B. \& SmolarzDuderewiczowa, J. Congenital hypoplasia of the eyeball (microphthalmia and anophthalmia). Klin. Oczna, 36(1): 65-8, 1966.

\author{
Correspondence to: \\ Dr. James Olopade \\ Department of Veterinary Anatomy \\ University of Ibadan \\ Ibadan \\ $\mathcal{N I G E R I A ~}$ \\ Email:jkayodeolopade@yahoo.com
}

Received : 09-08-2005

Accepted: 22-09-2005 